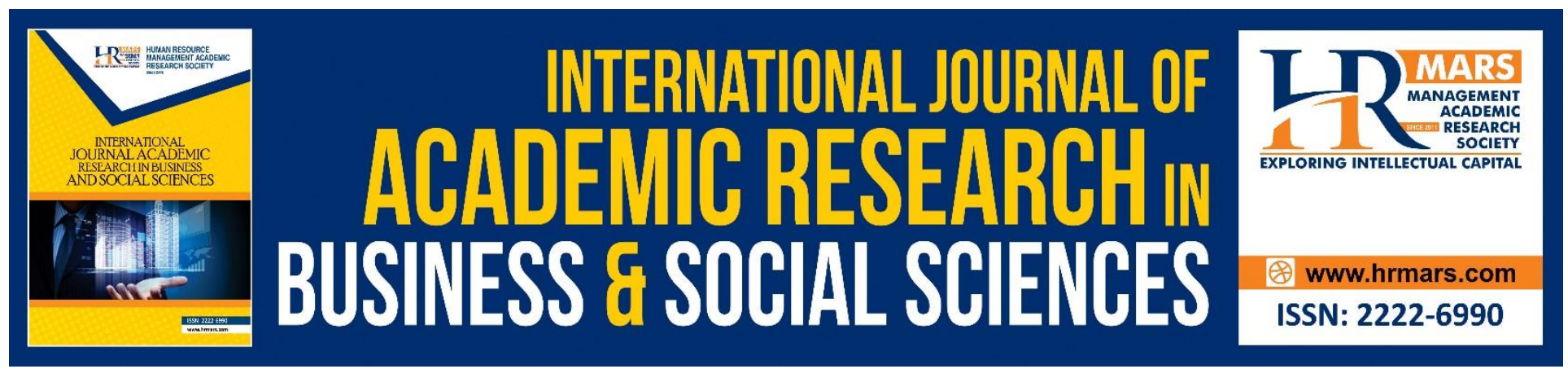

\title{
Malaysian Junior Voters' Perception on the Implications of National Budget on Voting Pattern
}

\author{
Hairol Anuar Mak Din and Lee Yok Fee
}

To Link this Article: http://dx.doi.org/10.6007/IJARBSS/v11-i15/10638

DOI:10.6007/IJARBSS/v11-i15/10638

Received: 12 May 2021, Revised: 16 June 2021, Accepted: 10 July 2021

Published Online: 28 July 2021

In-Text Citation: (Din \& Fee, 2021)

To Cite this Article: Din, H. A. M., \& Fee, L. Y. (2021). Malaysian Junior Voters' Perception on the Implications of National Budget on Voting Pattern. International Journal of Academic Research in Business and Social Sciences, 11(15), 112-122.

Copyright: (C) 2021 The Author(s)

Published by Human Resource Management Academic Research Society (www.hrmars.com)

This article is published under the Creative Commons Attribution (CC BY 4.0) license. Anyone may reproduce, distribute, translate and create derivative works of this article (for both commercial and non-commercial purposes), subject to full attribution to the original publication and authors. The full terms of this license may be seen

at: http://creativecommons.org/licences/by/4.0/legalcode

Special Issue: Empowering Youth and Community Wellbeing for Sustainable Development, 2021, Pg. 112 - 122 http://hrmars.com/index.php/pages/detail/IJARBSS JOURNAL HOMEPAGE

Full Terms \& Conditions of access and use can be found at http://hrmars.com/index.php/pages/detail/publication-ethics 


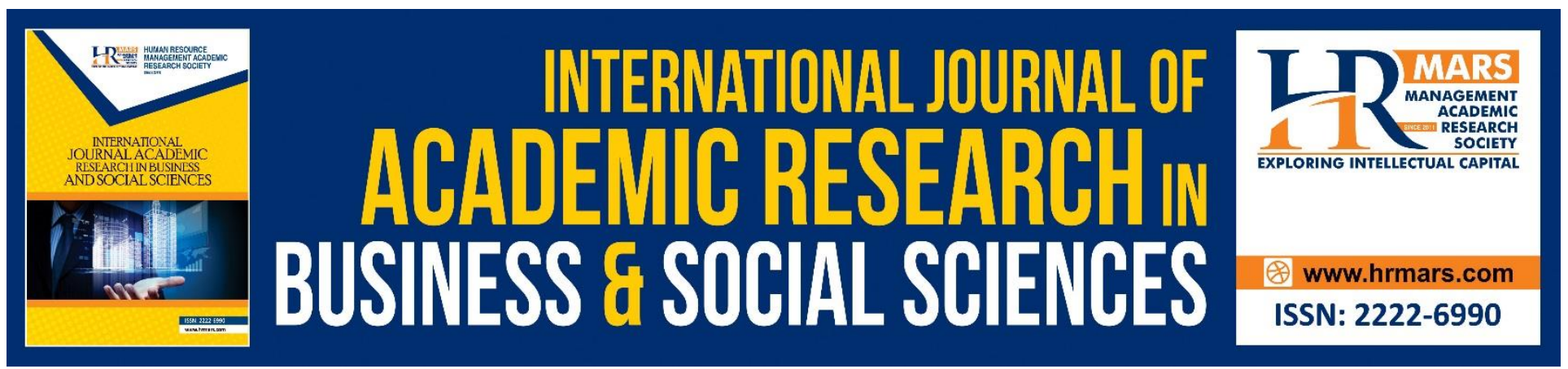

\title{
Malaysian Junior Voters' Perception on the Implications of National Budget on Voting Pattern
}

\author{
Hairol Anuar Mak Din ${ }^{3}$ and Lee Yok Fee ${ }^{1,2}$ \\ ${ }^{1}$ Institute for Social Science Studies, Putra Infoport, Universiti Putra Malaysia 43400 UPM Serdang, \\ Selangor, Malaysia, ${ }^{2}$ Faculty of Human Ecology, Universiti Putra Malaysia, 43400 UPM Serdang, \\ Selangor, Malaysia, ${ }^{3}$ International Islamic University College Selangor (KUIS), Bandar Seri Putra, \\ 43000 Kajang, Selangor Darul Ehsan. \\ Email: leeyokfee@upm.edu.my
}

\begin{abstract}
The national budget is a national agenda and functions as a catalyst in fulfilling the aims of national development. The national budget is also a practice of the executive institution in the manifestation of government power that is legitimately elected in a democratic system. Thus, the focus of this study is on the implications of the budget presentation to junior voters' voting pattern. The argument of this research is based on the model of Authoritative Value Allocation suggested by David Easton. The design of this study is based on a quantitative research design using the survey method. A total of 384 respondents were selected in this study with the purposive sampling technique and the number of the sample was determined by Krejie and Morgan's sample determination table. The findings of the study found that all levels of items in the model include; the surrounding environment, inputs, outputs, and feedback, help answer the research question. The evidence for the findings has been analyzed descriptively using percentage, mean, and standard deviation. The findings of the study conclude that the budget did bring significant implications on the junior voters' choice of political party in an election.
\end{abstract}

Keywords: National Budget, Value Distribution Process Model, Junior Voters, Democracy, Voting Preference.

\section{Introduction}

Generally, budgets represent decisions on what will and will not be achieved by the government. They represent the general opinion about what kind of services governments can provide and what people as citizens of society are entitled to. Budgets often reflect the degree of emphasis that lawmakers put on meeting their constituents and reacting to requests from interest groups. In addition, budgets represent the preferences of people for various types and levels of taxation, as well as the capacity of certain classes of taxpayers to transfer tax burdens to others (Rubin, 1990).

The national budget is an important national agenda that plays a role as a catalyst in achieving a national development plan. Because of the democratic system, budget is also an exclusive practice of executive jurisdiction in a legislative institution as preserved in the Federal Constitution of 
Malaysia. This is a manifestation of power that is legally applied in a system of government of a democratic country. This practice was inherited from British colonial after Malaysia achieved its independence, and is also widely practiced in most countries that practice a democratic system.

It is no doubt that the budgetary policies are heavily affected by the political actors who rule the country. On the other hand, to achieve the highest possible ranking, most fiscal policies are drawn up before elections and are introduced in order not to lose the sympathy of the electorates. In the practice of parliamentary democracy in Malaysia, the power of the people through voting is so important in determining the survival of the ruling political party. With this, a study on the implications of the budget presentation to the people has been conducted with a focus on junior voters as respondents.

Junior voters are categorized in the group of young voters registered with the Election Commission of Malaysia aged 21 to 40 years. The age range of 21 to 40 years is the largest demographic group with an estimated number of more than 30 percent among Malaysians. This number is so significant to the voting pattern because of their influential role and are very sensitive to national issues and policies. Therefore, this study of the implications of the Budget on junior voters is very relevant in shaping the political system as well as the determinants of government formation through elections.

\section{National Budget and Voting Pattern}

The changing trends of the political landscape can be traced through the history of General Elections in Malaysia. In the 12th General Election in 2008, the Barisan Nasional (BN) party, which governed the Federal Government, showed such a significant decline in votes that it failed to maintain a twothirds majority at the parliamentary level and also lost several states to opposition parties.

The divisive voting pattern and favoured towards the Opposition was also recorded in the 13th General Election. However, BN had to surrender the people's decision as the party was rejected by the people's vote in the 14th General Election which took place in 2018. Among the reasons for BN's defeat is due to the implementation of non-populist government decisions decided in the Budget Series presented such as the introduction and enforcement of the Goods and Services Tax (GST), the 1Malaysia People's Aid (BR1M), and implementation of mega projects that fail to be rationally justified in the political arena. which was later successfully manipulated by the Opposition.

BN's defeat is proof that the people's concerns were not being handled properly. Strong (1972) has stated that democracy is a pattern of government that depends on the consent and disapproval of many. The practices of political freedom in a democratic system can be manifested in activities like holding political dialogue, permission to hold protests and criticism, in addition to the rights to vote and participate in the election of members of the legislature and executive (Sen, 1999). The people participate in the government through the representatives wherein the context of Malaysia, the Member of Parliament, at the same time the people will also punish the representative or the party through the democratic process. Based on this understanding, the Budget segment is emphasized in this study by linking it to the voting pattern. Where through the presentation of the Budget official government decisions are introduced, approved, and repealed. Thus the people's reaction to the government's decision in Budget is evidence of the practice of political freedom. 


\section{National Budget in A Model of Value Allocation Process}

In a political system in which the various structures interact, there is a distribution or allocation of values by an authoritative power. This process was called by Easton (1965) "the authoritative allocation of values."

The existence of government or the use of authoritative terms by Easton is to emphasize the role of legitimate authority to carry out the task of allocating values through binding decisions of members in a system and the budget is part of it.

The budget is an official statement by the ruling government on the 'estimated revenue and expenditure estimation' for the next year which is used as a tool for planning and managing the country's economic resources to meet the needs of the people as a whole.

The Ministry of Finance Malaysia refers the budget to an estimation of the federal expenditure in one year which contains estimations of operating expenditures and development expenditures for a ministry and government department or agency to implement development programs, activities, and projects for the next year.

The basic concept of a budget is a government strategic planning document, while a budget or budget document is a product of a budget process. There are six elements of a budget as outlined by the National Institute of Accounting (2017), namely:

a. Government policies, goals, and strategies to be implemented in the next year of the budget.

b. Programs, activities, and projects that will be implemented to achieve the strategies and goals set.

c. Distribution of financial resources according to programs, activities, and projects.

d. How and how much revenue is collected to fund planned programs, activities, and projects.

e. Amount of financing from the source of the loan.

f. Output performance or impact targets.

Since the budget is bound up in the components of government (executive, legislative, and judiciary), the legal basis for reference to the budget is in Article 99 of the Federal Constitution which outlines the source of power as follows:

a. The Yang di-Pertuan Agong shall for each financial year, direct that an estimation of the income and expenditure of the Federation for the year be tabled in the Dewan Rakyat, the statement shall be so presented before the commencement of that year.

b. Budget components should consist of consolidated funds comprising of revenue component, loan component, and expenditure component.

c. The revenue component consists of tax income, non-tax revenue, non-revenue receipts, and revenue from the federal territories.

d. Government expenditure consists of, operating expenses, dependent expenses, supply expenses, development expenditure, direct development expenses, and indirect loans.

e. The types of budget are, a balanced budget, when revenue is balanced with expenditure; surplus budget, when total revenue exceeds expenditure; and budget deficit, when expenditure is more than total national revenue (National Institute of Accounting, 2017).

Therefore, it can be concluded that the budget is an expenditure plan based on income and expenses. The budget is based on goals, needs, and wants. Thus, the budget is an expenditure plan, which is a method to balance the money owned with the money spent (Era Konsumer Malaysia, 2011). 
Meanwhile, the prevalence of studies on voting behavior can also be referred to in the field

of political science. The field that studies the thinking flow of voters that influences voting patterns is called psephology. According to Hussein (1996), several key conclusions and hypotheses are aroused from these studies that serve as a general guide to those who are interested in studying the behavior of voters in a real context.

The most referred psephology scholars are Harris (1979); Rose (1974); Campbell (1966). Among the general guidelines for studying voter behavior in a real context, are:

a. Most people, including those who did not go out to vote, felt that elections, voting, and representation were good and beneficial.

b. In most liberal democratic countries between 80 percent to 90 percent of voters do not change the loyalty of their party, i.e., they continue to support the same party from one election to another.

c. But those who change their minds (or so-called 'floating voters') have a profound impact on election results.

d. Election campaigns before polling day did not influence much the decision of the majority of voters.

e. Manifestos and statements about the candidate or party's stance on issues also do not change the minds of voters much.

f. Mass media such as radio, television, and newspapers also do not influence voters much.

g. Most voters decide on a party or candidate based on variables such as class, religion, age, region, gender, and income.

$h$. The biggest influence is the influence of the family.

i. Most voters associate a party with certain images that are relatively fixed and they vote

based on this image (stereotype) rather than rational consideration on specific issues.

Thus, any government political decision through the presentation of the budget is so significant. This is because through the presentation of the budget, the government will get responses from the people directly and in the long run will also reflect on the position of the ruling party in the government.

\section{Methodology}

The design of this study is a quantitative research using a survey as a research method. An instrument in a questionnaire form was developed and employed to collect data. Survey is a research method that is easy to administer, easy to obtain the cooperation of respondents, and the questions posed are accompanied by suggested answers that allow answers to be given accurately and quickly (Majid, 2000).

In the process of constructing the instrument for this study, the items in the questionnaire were identified and constructed through library research. By using critical analysis (including historical methods, comparisons, and observations) and content analysis methods on the literature that related to the topic of the study.

Sampling is related to the process of selecting a number of subjects as respondents from a population of interest. Sampling is an important aspect of research because the use of inappropriate samples will reduce the validity and reliability of the study (Piaw, 2006). Sekaran (2003) argues that sample selection should be able to represent and generalize the entire population. Thus, several basic considerations have been used by researchers to determine the sample size in this study. This is to 
ensure that each member has the same opportunity to represent the population in this study (Ary et al. 1996).

In this study, the sampling method used was the purposive sampling method. This method refers to sampling in which a group of subjects with certain characteristics is selected as respondents (Piaw 2006). Therefore, in this study, the sample is limited to junior voters only that is respondents aged between 21 years to 39 years only.

The size of the sample for this study was determined by using the Krejcie \& Morgan (1970)'s Sample Size Determination Table, where the population size exceeds 100,000 people then the applicable sample is 384 people. Therefore 384 young voters aged between 21 to 39 years old were selected randomly for this research.

\section{Findings on the Implication of Budget for Voting}

The following Table 1 is the research findings based on questions asked to find out the responses of the junior voters to the implications of budget for voting. The findings of this study were analyzed through percentage score, mean and standard deviation of the respondents' responses on 26 items in the questionnaire. Measurement of the respondents' agreement on the items regarding the implication of budget for voting was using Likert Scales that rank 1 to 5 for strongly disagree, disagree, moderate agree, agree, and strongly agree. This measurement provides a general picture that reflects the impact of the budget on the respondents' voting preference. 
INTERNATIONAL JOURNAL OF ACADEMIC RESEARCH IN BUSINESS AND SOCIAL SCIENCES

Vol. 11, No. 15, Empowering Youth and Community Wellbeing for Sustainable Development, 2021, E-ISSN: 2222-6990 @ 2020 HRMARS

Table 1: The implication of Budget on voting pattern based on mean and standard deviation

No Items Mean $\begin{gathered}\text { Standard } \\ \text { division }\end{gathered} \quad$ Stage
1. The political party I chose in an election depends on the reduction of the national debt rate as presented in the budget.

3.68

.935
Moderate
high

2. The political party I chose in an election is related to the role of the budget for the future survival of the country.

3. The political party I chose in an election

Moderate high depends on the success of the government in addressing social problems as presented in the budget.

4. The political party I chose in an election depends on the giant government project as presented in the budget.

5. The political party I chose in an election depends on the recognition of the outside world for the development of the nation as mentioned in the Budget.

6. The political party I chose in an election

Moderate depends on the distribution of budget allocations in the development of the region.

7. The political party I chose in an election depends on the budget allocation for the

\section{Moderate high} B40 group.

8. The political party I chose in an election depends on the rate of inflation as

Moderate reported in the budget.

9. The political party I chose in an election depends on the budget allocation for the youth associations.

10 The political party I chose in an election

- depends on the budget allocation for the M40 group.

11 The political party I chose in an election depends on the unemployment rate as presented in the budget.

12 The political party I chose in an election depends on the aspect of security in the country as presented in the budget. 
13 The political party I chose in an election depends on the allocation based on race in the budget presentation.

14 The political party I chose in an election

. depends on the increase in the price of goods because of the budget presentation.

15 The political party I chose in an election

- depends on the announcement of the public sector Bonus in the budget presentation.

16 The political party I chose in an election depends on the price of oil that subsidized in the budget.

17 The political party I chose in an election

- depends on the abolition of road tolls as announced in the budget.

18 The political party I chose in an election

- depends on the setting of the minimum wage as set out in the budget.

19 The political party I chose in an election depends on the university study loan (PTPTN) issue as presented in the budget.

20 The political party I chose in an election

. depends on the implementation of the SST tax as announced in the budget.

21 The political party I chose in an election depends on the strengthening of the value of the Malaysian Ringgit as stated in the budget.

22 The political party I chose in an election

- depends on the amount of livelihood assistance provided in the budget.

23 The political party I chose in an election

- depends on the aspects of educational development planned in the budget.

24 The political party I chose in an election

. depends on the development of sports provided in the budget.

25 The political party I chose in an election

- depends on an increase in the electricity tariff rate as announced in the budget.

26 The political party I chose in an election depends on the speed of Internet access as presented in the budget.
3.51

1.028

Moderate high

.833

Moderate high

3.84

.865

Moderate high

.840

Moderate high

.908

Moderate high

3.96

.905

Moderate high

3.86

.894

Moderate high

.959

Moderate high

Moderate high

.835

Moderate high

4.03

.851

High

3.85

.809

Moderate high

3.86

.895

Moderate high

3.82

.931

Moderate high 


\begin{tabular}{cccc}
\hline Overall result & 3.84 & .612 & $\begin{array}{c}\text { Moderate } \\
\text { high }\end{array}$ \\
\hline
\end{tabular}

Source: Fieldwork 2019

Overall, the findings of the study found that all items showed mean scores between 3.51 to 4.03 which are at the levels of Moderate High and High. In summary, the overall result found that the implication of budget for respondents' voting preference is at 3.84 which is a moderately high level.

The findings of the study found that the twenty-third item regarding "the political party I chose in an election depends on the aspects of educational development planned in the budget" is at the highest level of mean at 4.03. Followed by the third item, i.e., "the political party I chose in an election depends on the success of the government in addressing social problems as presented in the budget", the second-highest item with the value of mean at 4.01 which is also in the high-level category. And the third highest item is the twelfth item (the political party I chose in an election depends on the aspect of security in the country as presented in the budget) which with a mean value of 4.0. It is also is in the category of high level.

The least popular item is the thirteenth item which is "the political party I chose in an election depends on the allocation based on race in the budget presentation" with a mean value of 3.51. The second-lowest is the first item with the value of mean at 3.68, and the item is "the political party I chose in an election depends on the reduction of the national debt rate as presented in the budget". The third lowest item is the fifth item, "the political party I chose in an election depends on the recognition of the outside world for the development of the nation as mentioned in the budget" and the mean value is 3.70. However, all these three items are still in the category of moderately high.

\section{Discussion and Summary of the Study}

In the study of voting patterns, political scientists tend to focus on the influence of political factors such as issues, political programs, electoral campaigns, and the popularity of party leaders over voting behavior (Campbell et al. 1980). Thus, in this study of voting patterns, the mentioned matters were scrutinized and analyzed in depth. With this, the items contained in this research influence the decisions that will be made by junior voters.

This justification is in line with the 'Feedback' component in the Model of Value Allocation Process. Feedback in this context is obtained from the results of the 'output' of the decision, and this action in turn will raise new questions as the various demands cannot be met either in part or in full.

Then there is feedback from this 'output' back to 'input', to new demands and the 'inputoutput mechanism will continue to work. This feedback also plays a role in adapting the system to new circumstances or the extreme imbalances in the relationship between the 'input' and the 'output' so that it continues to work and does not slip to threaten the existence of the political system itself.

Consequently, in line with the view of Hussein (1996) that the budget is an element contained in the basic factors of a person's involvement in political activities because it has to do with the pattern of cultural, economic, and political systems of society. This involves the relationship between the diversity of environmental dimensions and human action (Johnston et al. 2000).

The relevance of this feedback encompasses the human environment no matter is in the past, current, and future in all contexts including economic, political, and social. Apart from how it could influence the pattern and process of voting during elections. This is because the budget has significant 
implications for the involvement of society in the political system which is translated through voting as recorded in the system of Parliamentary Democracy practiced in Malaysia.

As we know, existing political parties aim to function as a channel to gain political power and governance. This is in line with Roy Macidis' definition of political parties as a tool to gain power (Robertson, 1982). Thus, the budget presentation is the most powerful strategy in attracting the people's support for the ruling party.

The findings of the study show that the implications of the budget for voting have found that the selection of political party in an election depends on the aspect of educational development is the most concerning item (mean 4.03 ) by the junior voters in the study. The issue of education is important in the chain of social life because through education the people can improve the living standard in the future. This is a continuation of the 'environmental atmosphere' component because the implication of budget for junior voters coincides with the view that the political system is moving in an environment around it as discussed in the Model of Value Allocation Process.

The results of the study also indicate that the item "the political party I chose in an election depends on the success of the government in addressing social problems as presented in the budget" which the mean value is 4.01 , is also highly concerned by the junior votes and influence their voting in an election. Issues in dealing with social problems are important and this is in line with the view of Carl Friedrich who argues that political parties are a group of people who carry out a ruling on security or appointing government leaders with other rulings for politicians in the party through control, views, and benefits that provide benefits for the people (Izani, 2007).

The third highest item is the item about "the political party I chose in an election depends on the aspect of security in the country as presented in the budget" at a mean value of 4.00 , which is also at a high level. This shows that junior voters are sensitive to security guarantees by the government. They will respond to the decisions made by the government if they think that the security issues are not taken into account.

Meanwhile, the lowest mean values item is about "the political party I chose in an election depends on the allocation based on race in the budget presentation" with the value of 3.51. This finding is in line with the view that in the new politics, multi-ethnic integration has begun to become a trend and to be followed (Rizal and Friday, 2002), thus the junior voters have shown an awareness of the need to vote for multi-ethnic political parties.

At the same time, the other two items, i.e., "the political party I chose in an election depends on the reduction of the national debt rate as presented in the budget", and "the political party I chose in an election depends on the recognition of the outside world for the development of the nation as mentioned in the budget" are the second lowest and third lowest mean value items. Both of the items' mean values are at 3.68 and 3.70 respectively. However, these items remain at a moderately high level.

The main implication of the budget is referring to the power of the people which is manifested in voting to select a political party. And Rodee and Clymer (1967) asserted that a party is a political organization and a societal representation created to dominate the government and compete with other groups to gain support. Based on the topic of this research, and referring to the components of the model discussed, it can be concluded that the study on the implication of budget presentation is significant. This is because through the presentation of the budget, different impacts have happened in people's lives and this article concludes that voters appreciate something they like and punish what they dislike based on the imperfections of a certain aspect of life that they concern about rather than on inaccurate or extreme perceptions. 


\section{Conclusion}

The national budget is significant for the people because it plays a role in shaping voter's preference toward a ruling political party. This is because, in a parliamentary democracy system, the power of the people is so important in determining the survival of the ruling party through a general election. Therefore, this study proves the importance of the budget for influencing the people, especially the implications of voters in making decisions in an election.

\section{References}

Ary, D., Jacobs, L. C., and Razavieh, A. (1996). Introduction to research in education. Florida: Harcourt brace College.

Campbell, A. (1966). Elections and the political order. New York: Wiley.

Chua, Y. P. (2006). Kaedah penyelidikan. Serdang: McGraw-Hill.

Cohen, J. (1977). Statistical power analysis for the behavioral science. New York: Academic Press.

Cronbach, L. J. (1972). The dependability of behavioural measurements: Theory of generalizability for scores and profiles. New York: Wiley.

Easton, D. (1965). A framework for political analysis. New Jersey: Prentice-Hall.

Era Konsumer Malaysia. (2011). Apa itu bajet? Retrieved from http://www.eraconsumer.org/stretching-your-ringgit/index.php/pengurusankewangan/484-apa-itu-bajet

Glassner, M. I. (1996). Political geography. New York: John Wiley and Sons.

Johnston, R. J., Gregory, D., \& Smith, D. M. (2000). The dictionary of human geography. Oxford: Blackwell.

Krejcie, R. V., dan Morgan, D. W. (1970). Determining sample size for research activities. Educational Psychological Measurement, 30, 608.

Malaysia. (2009). Federal constitution. Kuala Lumpur: International Law Book Services.

Mohd, I. (2007). Demokrasi dan dunia Islam: Perspektif teori dan praktik. Kuala Lumpur: Penerbit Universiti Malaya.

Mohd, M. K. (2000). Kaedah penyelidikan pendidikan. Kuala Lumpur: DBP.

National Institute of Accounting. (2017). Pengenalan kepada pengurusan kewangan dan sistem belanjawan negara. Retrieved from:

https://www.academia.edu/11423142/PENGENALAN_KEPADA_PENGURUSAN_KEWANGAN _and_SISTEM_BELANJAWAN_NEGARA

Rizal and Jumaat. (2002). Politik etnik dan perkembangan politik baru. In Politik baru dalam pilihanraya umum. Bangi: Penerbit UKM.

Robertson, A. H. (1982). Human rights in the world. New York: St. Martin.

Rodee, C. C., Anderson, T. J., \& Christol C. W. (1957). Introduction to political science. New York: McGraw Hill.

Rubin, I. S. (1990). The politics of public budgeting: Getting and spending, borrowing and balancing. Chatham, NJ: Chatham House Publishers.

Sen, A. (2006). The argumentative Indian. London: Penguin Books.

Strong, C. F. (1972). Modern political constitutions. London: English Language Books.

Syed, A. H. (1996). Pengantar sains politik. Kuala Lumpur: DBP.

Uma, S. (2003). Research methods for business: A skill-building approach. New York: John Willey \& Sons. 